\title{
On health protection and health related physical culture trainings of first year students
}

\author{
Fotynyuk V.G. \\ National Aviation University
}

\begin{abstract}
Purpose:

Material:

to assess health protection and health related physical culture trainings of first year students

Results:

in the research first year students ( $n=121 ; 86$ boys and 35girls of age $16-19$ years, participated.

components of students' individual health were found. Situation with health related physical culture trainings, ensuring students' sound health and optimal functional potentials of their organisms were determined. It was found that leading role shall be played by formation of health world vision values, knowledge about formation of practical skills in healthy life style. Motivation tendency for realization of intentions and practicing of health related physical culture trainings were found in students.

Conclusions: the received results prove students' tendency to pay insufficient attention to individual health. It was found that health related physical culture trainings require modern renewal of education's content, forms and methods of physical education. The basis of such trainings shall be health related orientation.

Keywords: questionnaire, students, health, program, functional.
\end{abstract}

\section{Introduction}

Students' physical education in higher educational establishments is and efficient factor in personality oriented teaching, in formation positive motives for systemic physical exercises' practicing, careful attitude to health. All these shall be the basis of youth's life activity.

Results of domestic scientists' woks witness about the following: there is significant quantity of students with low health level [3, 4, 6, 7]; increasing of students' quantity, who belong to special health groups $[1,5,16$, 33].

Scientists proved that great number of modern students have insufficient physical fitness [43] and poor somatic health. It is noted that insufficient motor functioning negatively influences on most of organism's functions and facilitates emersion of vegetative vascular dystonia [12, 14, 34].

One of obstacles for physical exercises' practicing is students' unsatisfactory health and physical fitness. The following main negative factors influence on youth's health: unsatisfactory organization of physical education in students' teaching. Scientists say that worsening of school age children's health is medical and pedagogic problem. The main task of comprehensive educational establishment shall be pupils' health protection and strengthening; formation of their responsible attitude to own health [2, 8, 11, 35].

Only $5 \%$ of adolescents remain to be healthy by the moment of secondary education finishing. $40-50 \%$ of school-leavers have substantial morphological functional disorders; 40-60\% - have chronic diseases. From 20\% to $80 \%$ of adolescents have pathologies in two - five human life provisioning systems [9]. It is facilitated by the absence of proper pedagogic control over schoolchildren's health [25].

Important components of sport and health related works among students are:

\footnotetext{
(c) Fotynyuk V.G., 2017

doi:10.15561/20755279.2017.0103
}

- Creation of healthy environment [19, 36, 37, 41];

- Substantiation of physical loads' level [18, 22, 23];

- Correction of deviations in different aspects of students' physical, psychic and social- moral health [17, 21, 29, 44];

- Influence of negative and harmful habits on students' organisms [13, 15, 32];

- Development of personality's components of healthy life style [31];

- $\quad$ Rising of health condition level and health at the cost of different modern training methods [31];

- Prevention from progressing of students' harmful computer habits [30];

- Organization of proper pedagogic control over students' health [24, 26, 27];

- Improvement of students' general and special physical qualities by sport trainings [20, 28, 39, 40].

Health improvement or sustaining on proper level shall be the main purpose of physical education classes. Possibility to assess students' health level is an important motivation factor for students' health related physical culture trainings. That is why it is important that usage of pedagogic experiments would give them confident information about their health. It will permit to select appropriate individual correction means for increasing motivation for health related physical culture trainings (especially for students with little deviations in health).

The purpose of the research is to assess health protection and health related physical culture trainings of first year students.

\section{Material and methods}

Participants: in the research first year students $(n=121$; 86 boys and 35girls of age 17 - 19 years, participated.

Organization of the research: students' attitude to own health was studied with the help of special questionnaire. The questionnaire contained questions about conditions of study and rest, influence of sports and physical exercises practicing on health, formation of health protection 
environment in university, quality of physical education trainings and other.

Statistical analysis: we used the methods of transformation of questioning empiric data. With the help of logic meaningful procedures we revealed correlations of the studied variables.

\section{Results}

For health assessment the students were offered to answer a number of questions. The question "how your health influences on results of your studying?" we received the following answers: 58\% of students understand importance of health for study progress; $38 \%$ think that health does not influence on study at all; $4 \%$ do not know how health influences on studying.

Students' answers concerning role of health in their lives were as follows: $41 \%$ - health is the main thing in life; $48 \%$ - health is necessary condition of full fledged life activity; $6 \%$ - there are other important values; 5\% want top live not thinking about health.

Students "determined the state of their health". Their self assessment was: $47 \%$ consider their health to be good; $37 \%$ - satisfactory; $16 \%$ think that their health is unsatisfactory.

In the questionnaire there was such question: "After medical examination at the beginning of academic year, to what health group you were related?" The answers were as follows: main health group - 75\%; special health group - 10\%; group of therapeutic physical culture (TPC) $-15 \%$.

Answering the question about possible influence of physical health on psychic self-feeling $43.5 \%$ noted that it influences; $56.5 \%$ think that health does not influence on psychic self-feeling.

Answering the question "is there dependence between study progress and physical health?” $48 \%$ of students understand the importance of physical health; $42 \%$ neglect health; $10 \%$ could not answer. Answers to question "which kinds of leisure do you prefer?" were: 78\% prefer passive leisure (TV, internet). Physical exercises and sports are preferred by $22 \%$. It should be noted that many students are oriented on passive leisure. Results of our questioning illustrate the results of other work [1]. The author found that the youth's interest to physical activity is rather at high place in structure of interests. But in many cases this interest is passive and not realized in practice.

Stress-factors are poor sleep, hunger, thirst, excessive physical loads and immobility [10]. Students' way of life was elucidated by their answers to question "how long your sleep lasts (day and night)". Answers showed that $50 \%$ of students sleep 5-6 hours; 4\% - less than 5 hours. In connection with deficit of sleep every second student is influenced by stress-factor. $46 \%$ of students pointed that their sleep lasts 7-8 hours.

Only $26 \%$ of students have normal eating - 3-4 times a day. More than half $-54 \%$ eat 2-3 times a day. 20\% feel fatigue and stress because of eating 1-2 times a day.

Among reasons of lectures' missing students noted reduction of adaptation that manifests in morbidity:
$24 \%$ are sick very rarely - once in several years; $36 \%$ - 1-2 times a year; 26 - once in semester. Extremely low adaptation level (diseases 1 time every month) was found in $14 \%$ of students.

It is known that strengthening of organism's reserves is possible by three means: physical, hypoxic training and hardening. That is why students' attitude to hardening for health improvement is rather interesting. $1 \%$ of students practice hardening constantly; 7\% - sometimes; $92 \%$ do not practice hardening at all.

Smoking is the main etiological factor of many heavy and fatal diseases of men and women. As per the data of World Health Protection organization 1.1 billion of people are tobacco-smokers [45]. The question "Do you smoke?" 56\% answered "Yes"; 34\% - sometimes. Only $10 \%$ of respondents answered "No". We think that active propaganda of smoking harm and struggle with it can reduce the number of adult smokers as far as just school age and students' age is the main source of adult smokers' population.

Students' alcohol drinking was studied by their following answers: "once a week and more often", "sometimes", "no". Alcohol drinking once a week and oftener is intrinsic to $14 \%$ of students; "sometimes" $82 \%$ of students and $4 \%$ do not drink alcohol at all.

In opinion of the most of students harmful habits are not the main reason of indifferent attitude to physical culture. However students' dependence on harmful habits is evident. It underlines again the difference between verbal and real attitude to healthy life style values.

Students' answers to the questionnaire's questions permitted to find their understanding of demand in health related physical culture classes. For this purpose the students were offered to answer the question, concerning significance of physical culture in realization of life plans and health preservation.

Analysis of answers showed that health related physical culture trainings are significant for $49 \%$ of students; by signs of usefulness and prestige - for $51 \%$. As it is known environmental conditions significantly influences on human attitude to different activities. That is why we interested how students assess conditions for health related physical culture training in places of their residence. The results showed that about $8 \%$ think that they are positive and $92 \%$ are not satisfied by environmental conditions. It can be considered to be one of reasons of their unwillingness to participate in health related trainings.

There was one more question: "Let's assume that in the place of your residence there are proper conditions for health related physical culture trainings (in any convenient for you time). Will your attitude change?"

80\% gave positive answer. Analysis of students' answers to all questions showed that the students have positive motivational base for health related trainings.

Next question was "do you practice health related physical exercises?" Answers to this question permitted to determine individual interests, motives and orientations in health related physical culture trainings. $23.1 \%$ of students 
answered positively. Thus, students' answers permitted to find results of formed in them positive motivation at the stage of desire realization; presence of targeted structure and realization plan. $71 \%$ of students practice physical exercises 1-3 times a week; $25.6 \%$ - 4-5 times a week; $2.7 \%$ - practice physical exercises 6-7 times a week.

Students' conscious attitude to independent health related physical culture trainings is formed under influence of subjective (internal) motives. The question "which personal motives force you to independent health related physical culture trainings?" permitted for us to mark out students' main internal motives. Results were as follows: $68 \%$ - health strengthening; $26 \%$ - physical perfection; 6\% - improvement of constitution. Study of motives for health related physical culture trainings permits to conclude that such trainings are connected to large extent with organism's health improvement. Thus, students' answers permit to find their motivation tendency for health related physical culture practicing.

\section{Discussion}

Modern requirements to students' health determine demand in comprehensive development of health protection and health related physical culture trainings of first year students. It shall be one of main directions of physical education process. The fulfilled by us study proves and supplements the works of domestic scientists $[3,4,6,7]$ about insufficient level of students' health and formation of healthy life style.
In our opinion worsening of students' health is connected with the fact that physical culture classes are stipulated only in the first year of study. Besides, it is connected with general shortening of physical education hours up to two hours a week. That is why physical education program requires further development and improvement of appropriate organizational methods. On the other hand - there is a demand in scientific substantiation of new ways of students' independent health related physical culture trainings.

The materials of our study expand idea about importance of health protection and health related physical culture trainings for first year students in conditions of modern education [1, 30-33]. The supplied facts witness that students have no formed positive motivation for health related physical culture trainings.

\section{Conclusions}

Basing on results of our questioning we found that most of students pay insufficient attention to health protection and health related physical culture trainings as to component of their life activity. For formation of students' positive attitude to health protection and health related physical culture trainings it is necessary to form, first of all, world vision values in respect to health; to give knowledge about practical skills in healthy life style practicing.

\section{Conflict of interests}

The author declares that there is no conflict of interests.

\section{References}

1. Belykh SI. Health, physical education and physical development of students in historically and personally developing paradigm. Pedagogics, psychology, medicalbiological problems of physical training and sports, 2013;5:7-12. doi:10.6084/m9.figshare.707091

2. Bodnar IR, Andres AS. Tests and standards for expresscontrol of physical fitness and health of middle school age pupils. Pedagogics, psychology, medical-biological problems of physical training and sports, 2016;4:11-16. doi:10.15561/18189172.2016.0402

3. Bondarenko SV, Darzinska NO, Sidilo LV. Formation of 17-18 yrs age girl students' visual performance by means of visual training at stage of adaptation to learning loads. Pedagogics, psychology, medical-biological problems of physical training and sports, 2015;4:10-15. doi:10.15561/18189172.2015.0402

4. Gakman A. Riven' zdorov'ia i zakhvoriuvanosti studentiv VNZ gumanitarnikh special'nostej [Health level and morbidity of HEE students of humanitarian specialties]. Fizichna kul'tura, sport ta zdorov'ia nacii, 2015;19(1):7178. (in Ukrainian)

5. Hnyp IYa. Assessment of functional status and quality of life of students after acute respiratory viral diseases. Pedagogics, psychology, medical-biological problems of physical training and sports, 2015;3: 10-14. doi:10.15561/18189172.2015.0302

6. Griban GP. Analiz prichin i naslidkiv niz'kogo stanu zdorov'ia studentiv [Analysis of reasons and after effects of

students' low health level]. Naukovo-pedagogichni problemi fizichnoi kul'turi, 2011;15(10):207 - 211. (in Ukrainian)

7. Gruzhevsky VA. Health as a value in the formation of studentcentered motivation of students to physical education. Pedagogics, psychology, medical-biological problems of physical training and sports, 2014;2:20-24. doi:10.6084/ m9.figshare.926506

8. Davydova TM. Formation of schoolchildren's healthy life style culture as one of key problems of modern comprehensive educational establishment. Pedagogics, psychology, medical-biological problems of physical training and sports, 2015;10:18-23. doi:10.15561/18189172.2015.1003

9. Kirilenko SV. Social'no-pedagogichni umovi formuvannia kul'turi zdorov'ia starshoklasnikiv. Kand. Diss. [Socialpedagogic conditions of health culture formation in senior school pupils. Cand. Diss.], Kiev; 2004. (in Ukrainian)

10. Marishchuk VL, Evdokimov VI. Povedenie i samoreguliaciia cheloveka $v$ usloviiakh stressa [Human behavior and self regulation in stress conditions], Sankt Petersburg: September; 2001. (in Russian)

11.Macejko I, Galandzovs'kij S. Somatichne zdorov'ia ta fizichna pidgotovlenist' divchat 7- 17 rokiv [Somatic health and physical fitness of 7-17 years' age girls]. Fizichna kul'tura, sport ta zdorov'ia nacii, 2015;19(1):293 - 298. (in Ukrainian)

12.Olchovik A V. Physical development and physical preparedness of students of special medical group with the disease of vegetative-vascular dystonia of mixed type. Pedagogics, psychology, medical-biological 
problems of physical training and sports, 2015; 3: 38-45. doi:10.15561/18189172.2015.0306

13. Abar B, Ogedegbe C, Dalawari P, Freeman K, Boudreaux ED, Illuzzi F, et al. Promoting tobacco cessation utilizing pre-health professional students as research associates in the emergency department. Addictive Behaviors. 2015;40(0):73-6.

14.Alfrey L, Gard M. A crack where the light gets in: a study of Health and Physical Education teachers' perspectives on fitness testing as a context for learning about health. AsiaPacific Journal of Health, Sport and Physical Education, 2014;5(1):3 - 18.

15.Al-Hariri MT, Al-Hattami AA. Utilization of internet by health colleges students at the University of Dammam. Journal of Taibah University Medical Sciences. 2015;10(1):66-73.

16.Asude Malkoç. Quality of life and subjective well-being in undergraduate students. Procedia - Social and Behavioral Sciences, 2011;15:2843-2847.

17.Berger H, Franke GH, Hofmann F-H, Sperth M, HolmHadulla RM. Mental health of students and its development between 1994 and 2012. Mental Health \& Prevention, 2015;3(1-2):48-56.

18.Bliznevsky AA, Kudryavtsev MD, Iermakov SS, Jagiello W. Formation of active-effective attitude of 12-13 years' judo athletes to sports functioning in competition period. Archives of Budo, 2016;12:101-15.

19.Dolan E, Hancock E, Wareing A. An evaluation of online learning to teach practical competencies in undergraduate health science students. The Internet and Higher Education. 2015;24(0):21-5.

20.Gaskov AV, Kuzmin VA, Kudryavtsev DM, Iermakov SS. Successfulness of general and special physical qualities' development on different stage of students-boxers' training. Physical Education of Students. 2016;20(1):4-11. doi:10.15561/20755279.2016.0101

21.Hadden KB. Health literacy training for health professions students. Patient Education and Counseling. 2015;98(7):91820.

22.Iermakov SS, Arziutov GN, Jagiello W. Quick training of students to judo techniques. Archives of Budo. 2016;12:1524.

23.Iermakov SS, Podrigalo LV, Jagiello W. Hand-grip strength as an indicator for predicting the success in martial arts athletes. Archives of Budo, 2016; 12, 179-186.

24.Ivashchenko O, Khudolii O, Iermakov S, Lochbaum MR, Cieslicka M, Zukow W, Nosko M, Yermakova T. Intra-group factorial model as the basis of pedagogical control over motor and functional fitness dynamic of 14-16 years old girls. Journal of Physical Education and Sport, 2016; 16(4), 1190 - 1201. doi:10.7752/jpes.2016.04190

25.Ivashchenko O, Khudolii O, Yermakova T, Iermakov S, Nosko M, Nosko Y. Factorial and discriminant analysis as methodological basis of pedagogic control over motor and functional fitness of 14-16 year old girls. Journal of Physical Education and Sport, 2016;16(2), 442-451. doi:10.7752/ jpes.2016.02068

26.Kopeikina EN, Drogomeretsky VV, Kondakov VL, Kovaleva MV, Iermakov SS. Modification of Harvard step-test for assessment of students' with health problems functional potentials. Physical Education of Students, 2016;4:44-50. doi:10.15561/20755279.2016.0405

27.Kozina ZL, Iermakov SS, Kadutskaya LA, Sobyanin FI, Krzeminski M, Sobko IN, Ryepko OA. Comparative characteristic of correlation between pulse subjective indicators of girl students' and school girls' reaction to physical load. Physical Education of Students, 2016;4:2434. doi:10.15561/20755279.2016.0403

28.Kozina Z, Sobko I, Yermakova T, Cieslicka M, Zukow W, Chia M, Goncharenko V, Goncharenko O, Korobeinik V. Psycho-physiological characteristics of female basketball players with hearing problems as the basis for the technical tactic training methodic in world level teams. Journal of Physical Education and Sport, 2016; 16(4), doi:10.7752/ jpes.2016.04213

29.Kudryavtsev MD, Kopylov YuA, Kuzmin VA, Ionova OM, Yermakova TS. Personality oriented system of strengthening of students' physical, psychic and socialmoral health. Physical Education of Students, 2016;3:58-64. doi:10.15561/20755279.2016.0308

30.Kudryavtsev MD, Kramida IE, Iermakov SS. Influence of studying in higher educational establishment on students' harmful computer habits. Physical Education of Students, 2016;5:17-23. doi:10.15561/20755279.2016.0503

31.Kudryavtsev MD, Kramida IE, Iermakov SS, Osipov AYu. Development dynamic of healthy life style personality componentinrelativelyhealthystudents.PhysicalEducation of Students, 2016;6:26-33. doi:10.15561/20755279.2016.0603

32.Kudryavtsev MD, Kramida IE, Kuzmin VA, Iermakov SS, Cieslicka Miroslawa, Stankiewicz Blazej. Influence of study in hee on ubiquity and strength of students' computer gambling. Physical Education of Students, 2016;3:13-22. doi:10.15561/20755279.2016.0302

33.Korol SA. Assessment of physical health and physical fitness of students of technical specialties of I course. Pedagogics, psychology, medical-biological problems of physical training and sports, 2014;11:23-29. doi:10.15561/18189172.2014.1105

34.Llopis J, Braddick F. Mental Health in Youth and Education. European Communities. 2008;1:37-41.

35.Maradova E. Transformation of Education towards Health in Czech Schools and Current Trends in Teacher Training. European Journal of Physical \& Health Education 2009;2:75 -80 .

36.Myers SS, Gaffikin L, Golden CD, Ostfeld RS, H. Redford K, H. Ricketts T. Human health impacts of ecosystem alteration. Proceedings of the National Academy of Sciences. 2013;19(47):18753-60.

37.Nosko M, Razumeyko N, Iermakov S, Yermakova T. Correction of 6 to 10-year-old schoolchildren postures using muscular-tonic imbalance indicators. Journal of Physical Education and Sport, 2016; 16(3), 988-999. doi:10.7752/ jpes.2016.03156

38.Osipov AYu, Kudryavtsev MD, Kramida IE, Iermakov SS, Kuzmin VA, Sidorov LK. Modern methodic of power cardio training in students' physical education. Physical Education of Students, 2016;6:34-39. doi:10.15561/20755279.2016.0604

39.Podrigalo LV, Iermakov SS, Alekseev AF, Rovnaya OA. Studying of interconnections of morphological functional indicators of students, who practice martial arts. Physical Education of Students. 2016;20(1):64-70. doi:10.15561/20755279.2016.0109

40.Podrigalo L, Iermakov S, Rovnaya O, Zukow W, Nosko, M. Peculiar features between the studied indicators of the dynamic and interconnections of mental workability of students. Journal of Physical Education and Sport, 2016; 16(4), 1211 - 1218. doi:10.7752/jpes.2016.04193

41.Pomeshchikova IP, Shevchenko OO, Yermakova TS, Paievskyi VV, Perevoznyk VI, Koval MV, . . . Moiseienko OK. Influence of exercises and games with ball on coordination abilities of students with disorders of muscular 
skeletal apparatus. Journal of Physical Education and Sport, 2016. 16(1), 146-155. doi:10.7752/jpes.2016.01024

42.Sandercock GRH, Ogunleye A, Voss C. Associations between showering behaviours following physical education, physical activity and fitness in English schoolchildren. European Journal of Sport Science. 2016;16(1):128-134.

43.Serorez TB. The indicators of the physical health of students on the characteristics of the physical fitness, aerobic and anaerobic productivity of their body. Pedagogics, psychology, medical-biological problems of physical training and sports, 2014;9:54-59. doi:10.5281/zenodo.10129
44.Skurikhina NV, Kudryavtsev MD, Kuzmin VA, Iermakov SS. Fitness yoga as modern technology of special health groups' girl students' psycho-physical condition and psychosocial health strengthening. Physical Education of Students, 2016;20(2):24-31. doi:10.15561/20755279.2016.0204

45. World health statistics 2016: monitoring health for the SDGs, sustainable development goals. (NLM classification: WA 900.1) [Internet] 2016 Nov 1 [cited 2016 Nov 8]. Available from: http://www.who.int/gho/publications/world_health_ statistics/2016/en/

Information about the author:

Fotynyuk V.G.; http://orcid.org/0000-0002-5483-7039; biohazard6666@ukr.net; National Aviation University; pr. Komarova 1, 03058, Kiev, Ukraine.

Cite this article as: Fotynyuk VG.On health protection and health related physical culture trainings of first year students. Physical education of students, 2017;1:17-21. doi:10.15561/20755279.2017.0103

The electronic version of this article is the complete one and can be found online at: http://www.sportedu.org.ua/index.php/PES/issue/archive

This is an Open Access article distributed under the terms of the Creative Commons Attribution License, which permits unrestricted use, distribution, and reproduction in any medium, provided the original work is properly cited (http://creativecommons.org/licenses/by/4.0/deed.en).

Received: 03.01.2016

Accepted: 21.01.2017; Published: 10.02.2017 